\title{
Extreme Ground Snow Loads in Europe from 1951 to 2100
}

\author{
Pietro Croce (1), Paolo Formichi (i) and Filippo Landi *(D) \\ Department of Civil and Industrial Engineering-Structural Division, University of Pisa, Largo Lucio Lazzarino 1, \\ 56122 Pisa, Italy; p.croce@ing.unipi.it (P.C.); p.formichi@ing.unipi.it (P.F.) \\ * Correspondence: filippo.landi@ing.unipi.it; Tel.: +39-339-1981604
}

Citation: Croce, P.; Formichi, P.;

Landi, F. Extreme Ground Snow

Loads in Europe from 1951 to 2100.

Climate 2021, 9, 133. https: / /

doi.org/10.3390/cli9090133

Academic Editors: Mário

Gonzalez Pereira and

Steven McNulty

Received: 26 June 2021

Accepted: 23 August 2021

Published: 25 August 2021

Publisher's Note: MDPI stays neutral with regard to jurisdictional claims in published maps and institutional affiliations.

\begin{abstract}
Lightweight roofs are extremely sensitive to extreme snow loads, as confirmed by recently occurring failures all over Europe. Obviously, the problem is further emphasized in warmer climatic areas, where low design values are generally foreseen for snow loads. Like other climatic actions, representative values of snow loads provided in structural codes are usually derived by means of suitable elaborations of extreme statistics, assuming climate stationarity over time. As climate change impacts are becoming more and more evident over time, that hypothesis is becoming controversial, so that suitable adaptation strategies aiming to define climate resilient design loads need to be implemented. In the paper, past and future trends of ground snow load in Europe are assessed for the period 1950-2100, starting from high-resolution climate simulations, recently issued by the CORDEX program. Maps of representative values of snow loads adopted for structural design, associated with an annual probability of exceedance $p=2 \%$, are elaborated for Europe. Referring to the historical period, the obtained maps are critically compared with the current European maps based on observations. Factors of change maps, referred to subsequent time windows are presented considering RCP4.5 and RCP8.5 emission trajectories, corresponding to medium and maximum greenhouse gas concentration scenarios. Factors of change are thus evaluated considering suitably selected weather stations in Switzerland and Germany, for which high quality point measurements, sufficiently extended over time are available. Focusing on the investigated weather stations, the study demonstrates that climate models can appropriately reproduce historical trends and that a decrease of characteristic values of the snow loads is expected over time. However, it must be remarked that, if on one hand the mean value of the annual maxima tends to reduce, on the other hand, its standard deviation tends to increase, locally leading to an increase of the extreme values, which should be duly considered in the evaluation of structural reliability over time.
\end{abstract}

Keywords: climate change; extremes; European climatic actions maps; ground snow loads; Eurocodes

\section{Introduction}

Impacts of climate change in several relevant societal and political sectors will become more severe in coming decades [1]. Looking at the available climate observations, a clear consequence of global warming is that the probability of occurrence of extreme weather and climate events has generally increased [2-5]. Aiming to make key economic and policy sectors more resilient to climate change, reduction of disaster risks and development of adaptation strategies have become global and European priorities [5].

Focusing on civil engineering structures and infrastructures, the challenge is the assessment of projected changes in extremes of climatic actions over time [6-9]. In structural engineering, variable actions connected to climate, such as wind, snow, precipitation, temperature and so on, are commonly referred to as "climatic actions" [10,11]. The representative values of such actions are associated with specified probabilities of being exceeded during a given reference period: e.g., the characteristic value in EN1990 corresponds to $p=2 \%$ in one year [10]. The representative values are usually determined by elaborating extreme measurements covering a period of 40-50 years, assuming the climate as stationary over time. To consider the influence of changing climate, suitably extended data series 
should be handled, including available past observations as well as future projections provided by climate models [12].

Trends of extreme temperature, precipitation and snow loads in Europe based on observations and reanalysis data have been recently discussed by the authors in [13]. In this paper, the study is extended to ground snow loads considering high resolution climate projections.

Impacts of climate changes on temperature and precipitation are commonly assessed using climate projections [2-5], while little has yet been done for snow [14], although it represents a significant climate variable. In addition to the complexity of the snow accumulation phenomena, it must be remarked that, on the one hand, changes in snow parameters cannot be appreciated by using only general or global circulation models (GCMs), having low grid resolution (>100 km) [14]. On the other hand, regional climate models (RCMs) with adequate grid resolutions $(10-50 \mathrm{~km}$ ) have been developed only in recent time. In any case, it is often necessary to rely on sophisticated snow models forced by climate projections of temperature and precipitation $[6,7,15]$.

Recent collapses of large-span lightweight roofs $[6,7,16-18]$ confirmed that extreme snow loads can cause significant economic damages and causalities [19]. A discussion about the reliability and failure of roofs subjected to snow loads can be found in [20] where a total of 249 roof collapses during the winter 2005/2006 is investigated identifying main observed causes into human errors and insufficient code provisions. Aiming to assess trends of extreme values of snow loads, a general methodology is presented in [6] and [7]. This procedure, combining available projections of daily minimum and maximum temperature and precipitation with site specific information on snowfall accumulation and melting processes, has been successfully applied to some specific regions in [8], and for the evaluation of long-term structural reliability too [21].

In climate impact studies for engineering applications, a common way to represent climate change induced variations is the "factor of change" (FC) or "change factor" approach [22-25], which "employs the (climate) model's response to climate change to modify observations" [23]. Although in other contexts, like specific climatology studies FC can be associated to change of other relevant physical variables such as solar radiation and land use or land cover and so on, in the following factors of change (FCs) are used consistently with their definition in [22-25], for assessing impact on climate variables relevant in engineering applications.

In this paper, an assessment of changes of ground snow loads from 1951 to 2100 at European scale is presented considering climate projections of snow water equivalent recently made available within the EURO-CORDEX initiative $[26,27]$ according to different scenarios [28]. First, ground snow load maps for characteristic values, i.e., 0.02 probability of exceedance in one year [10], obtained from climate projections for the historical period are discussed in comparison with the current European maps, based on observations. Then, FC maps elaborated for subsequent time windows are presented considering a climate model ensemble and different scenarios. These FCs are thus compared with long series of point observations at selected weather stations in Switzerland and Germany, so assessing the suitability of climate projections to capture current and past trends of snow water equivalent.

The influence of climate change on structural reliability represents also a challenging task in the ongoing revision of structural Eurocodes, requested to the European Committee for Standardization (CEN) by the European Commission [29,30].

\section{Material and Methods}

\subsection{Snow Loads}

Snow load on structures $s$, is usually determined from the snow load on ground, $s_{k}$, using a suitable loading chain, like

$$
s=s_{k} C_{e} \mu_{i} C_{t},
$$


where $C_{e}$, the exposure coefficient, depending on the orographic conditions of the neighborhood of the construction, on the shelter effect of trees and other surrounding construction works, and on wind velocity, accounts for the removal or the accumulation of snow on roof exerted by wind; $\mu_{i}$, the shape coefficient, which is a function of the shape and extension of the roof, and on the presence of taller adjacent constructions, is used to convert the ground into the roof snow load as well as to model possible non-uniform snow distributions on roof; finally $C_{t}$, the thermal coefficient, accounts for changes in the snow cover caused by the heat flux through the roof.

In the snow load model, the key information for structural design is snow load on ground [31]. In modern codes and standards, representative values of snow load on ground, characterized by a given annual probability of exceedance, are usually derived by extreme statistics, analyzing measurements of snow cover depth or of snow water equivalent (SWE) $[32,33]$. In the past, the SWE was measured directly only in some weather stations of European countries such as Germany, Finland, Switzerland and partially UK, in the other cases, the height of snow cover was converted into snow load by means of analytical snow density laws depending on the climatic conditions and the snow lasting period [33].

In Europe, snow loads are defined in the Eurocode EN1991-1-3 [34], where an annual probability of exceedance equal to 0.02 of the time-varying part is considered. In the Eurocode, a loading chain format according to Equation (1) is adopted, but several ongoing studies are improving the formulation of design shape coefficients [35] and the main results are being introduced in the new revised version of the EN1991-1-3 standard. Maps of climatic actions are given in National Annexes to Eurocodes, since they are Nationally Determined Parameters (NDPs). A detailed discussion concerning the definition of snow load maps in Eurocodes, and the actual situation of European harmonization based on Eurocode recommendations and national provisions can be found in [31].

Despite the different methods adopted for the statistical treatment of extremes, the elaboration of climatic action maps in European countries, including ground snow load, is based on the extreme value statistics covering a time period of 40-50 years. In the statistical analysis, climate is hypothesized stationary over time, although that assumption potentially leads to an underestimation of possible consequences of climate change.

The general methodology to elaborate snow load maps can be resumed as follows:

- First, annual extremes are collected for the considered period in a proper set of weather stations adequately spread over the investigated area;

- Then, available data for each weather station are fitted to an appropriate extreme value probability distribution, in such a way that representative values can be derived. In Europe, a Gumbel (EVI) distribution is generally adopted for annual maxima [31,33,36], including also non-snowy winters, following a "mixed distribution approach" [31,37];

- After that, homogenous climatic zones, which are characterized by a common loadaltitude relationship, are identified;

- Finally, isopleths are drawn to show the variation of the load within the considered geographic area.

The background study for definition of roof and ground snow loads in Europe was the European Snow Load Research Project (ESLRP) [33], led by the university, involving 18 CEN countries. In this project, snow data series from approximately 2600 weather stations were analyzed according to a common approach. Ten climatic regions were identified for snow loads (Iceland, UK and Eire, Norway, Finland and Sweden, Central West, Central East, Alpine, Iberian Peninsula, Mediterranean Region, Greece), and adopted in EN1991-1-3 [34] (see Figure 1). 


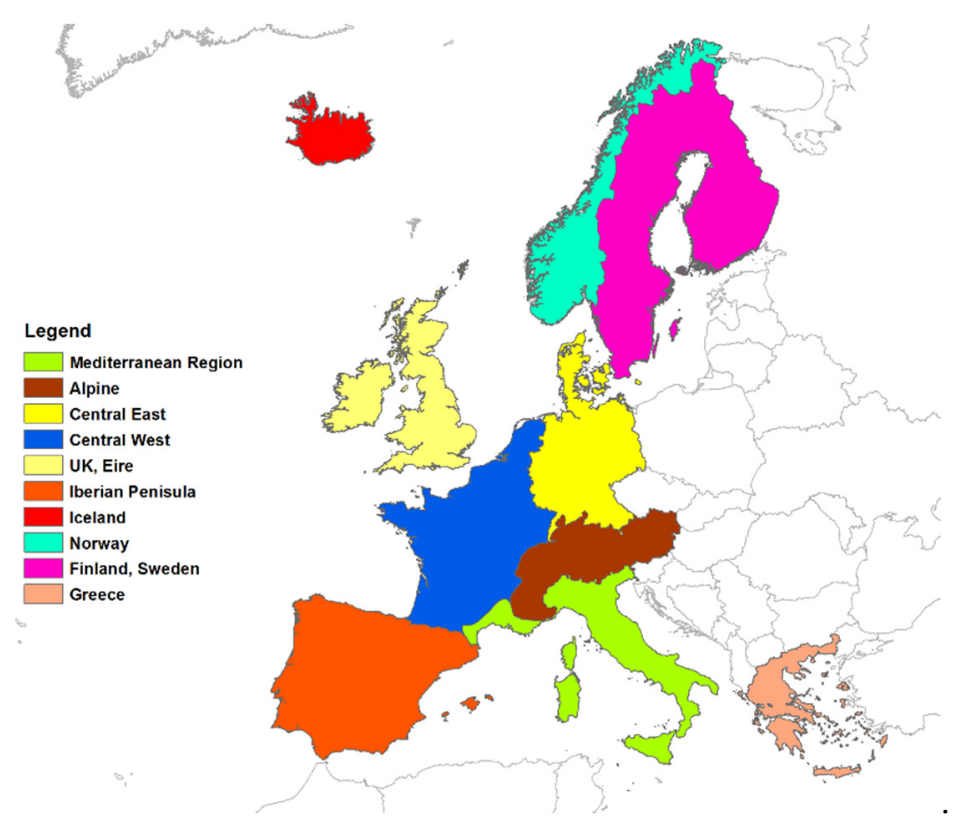

Figure 1. Climatic regions defined in Annex C of EN1991-1-3, based on the results of the ESLRP.

The snow load maps, given in [34], were the reference for each country to develop the National Maps provided in the National Annexes. Due to the different approaches and methodologies adopted country by country, the National Maps suffer from some inconsistencies especially across the borders, further emphasized by lack of homogeneity of available data [31].

In view of future revisions, there is still a strong need for a harmonized definition of snow parameters across different countries and for an update of current values, also considering more recent measurements, as well as information provided by satellite networks, reanalysis and climate models. In this framework, the evaluation of snowfall response to global warming is a challenging task. Although a decrease of snowfalls is expected on average, global warming can have diverging effects on extremes; in fact, the drop of snowfall fraction of precipitation is associated with an increase of precipitation rate during extreme events [38]. The temperature rise, on the one hand, facilitates the melting of snow and increases the fraction of precipitation falling as rain, on the other hand, it can increase the intensity of the single snow events, leading to higher ground snow loads [39]. For example, increasing trends in intensity and frequency of daily heavy precipitation have been already observed, even over the Alps [40,41], confirming theory and early models [4,42].

Decreases of SWE extremes, and snow cover duration are generally predicted for central Europe at the scale of Global Climate Models (GCMs), like those provided by the Coupled Model Intercomparison Project (CMIP3 and CMIP5) [43] within the World Climate Research Program (WCRP). However, the coarse resolution of GCMs is not able to capture topographic features, which are extremely relevant in the assessment of snow variables.

First, evaluations of changes in snow parameters based on Regional Climate Models (RCMs) are discussed in $[44,45]$. These studies were based on low resolution models, 49 and $25 \mathrm{~km}$ horizontal grid resolution for [44,45], respectively, considering the previous generation of forcing emission scenarios [46].

The rise of intensities of extreme snow precipitation can cause not only more severe snow loads, but also increased risk of ice accretion on structures particularly sensitive to atmospheric icing, like power lines and communication towers [44]. The relevance of heavy snowfalls is confirmed by events occurred in the last years, which affected central Europe in Winter 2005/2006 [16,17,20], central Italy in January 2017, southern Germany in 2019 [47], and Madrid in January 2021. Possible correlation of extreme winter event 
with arctic amplification has been assessed in [48], however, not enough evidence has been found [49].

\subsection{Datasets}

Aiming at evaluating the evolution of snow load on ground in Europe, the climate model data produced by the EURO-CORDEX initiative $[25,26]$, which are provided by the Earth System Grid Federation (ESGF), are considered in the following, focusing on snow variables [14]. Daily snow water equivalent data were collected from the combination of nine global and regional climate models as described in Table 1. The nine GCMs/RCMs were chosen for the availability of climate projections for both RCP4.5, medium scenario with stabilization of radiative forcing due to climate policy measures to limit emissions, and RCP8.5, representative of the highest emissions and non-climate policy scenarios. These scenarios are generally adopted in impact studies due to the higher availability of climate model runs with respect to RCP2.6 and RCP6. The discussion about the applicability of climate change scenarios is rapidly evolving and at present, RCP4.5 appears to offer more realistic baselines [50] while the use of RCP8.5 is debated within the scientific community $[51,52]$.

Table 1. Description of the main characteristics of the of the members of climate model ensemble used in the study. Data are provided for the historical, RCP4.5 and RCP8.5 experiment by the following Institutions: the Climate Limited-area Modeling Community (CLMcom), the Danish Meteorological Institute (DMI), Royal Netherlands Meteorological Institute (KNMI), the Max Planck Institute (MPICSC) and the Laboratoire des Sciences du Climat et de l'Environnement-Institute Pierre Simon Laplace (IPSL-INERIS).

\begin{tabular}{cccc}
\hline Model Acronym & Institution Acronym & Driving GCM & RCM \\
\hline EC-EARTH-CCLM & CLMcom & ICHEC-EC-EARTH & CCLM4-8-17 \\
HadGEM2-CCLM & CLMcom & MOHC-HadGEM2-ES & CCLM4-8-17 \\
MPI- CCLM & CLMcom & MPI-M-MPI-ESM-LR & CCLM4-8-17 \\
EC-EARTH- & DMI & ICHEC-EC-EARTH & HIRHAM5 v2 \\
HIRHAM & DMI & MOHC-HadGEM2-ES & HIRHAM5 v2 \\
HadGEM2-HIRHAM & KNMI & ICHEC-EC-EARTH & RACMO 22E \\
EC-EARTH-RACMO & MPI-CSC & MPI-M-MPI-ESM-LR & Remo 2009 \\
MPI-Remo2009 & MPI-CSC & NCC-NorESM1-M & Remo 2015 \\
NCC-Remo2015 & IPSL-INERIS & IPSL-IPSL-CM5A-MR & WRF381P \\
IPSL-WRF381P & & &
\end{tabular}

The selected RCMs provide not only future projections for the period 2006-2100, but also historical simulations for the period 1951-2005. Therefore, the historical run and the RCPs ones are merged to obtain two series of SWE for the period 1951-2100.

Since the outcome of each climate model can represent an independent sample of future climate, a combination of available models, as large as possible, should be considered to increase the robustness of the assessment. The opportunity to adopt a multi-model ensemble for climate change studies is presented and discussed in [53]. A methodology to enlarge the number of simulations, which are strictly limited by the huge computational time of climate model runs, thus increasing the statistical representatives of the ensemble, has been previously presented by the authors in [54,55]. Statistical adjustment procedures based on data augmentation and Bayesian inference are presented in [56] and recently applied to large RCM ensemble for the assessment of uncertainty associated to the expected changes in mean temperature and total precipitation in Europe [57].

Regarding climate projections of snow variables, some inconsistencies were already identified in previous studies for high altitude cells [14], usually above $1500 \mathrm{~m}$. For example, the snow accumulation process may lead to cells characterized by constant snow cover, and unrealistic snow accumulation. This result is not surprising since the resolution and the refinement of the climate model does not allow to capture huge local variations; for this 
reason, the grid cells affected by unrealistic snow accumulation, higher than $70 \mathrm{kN} / \mathrm{m}^{2}$ according to [14], were disregarded in the elaboration of RCMs outputs.

\subsection{The Factor of Change Approach}

Trends will be assessed in Section 3.2 according to common practice for engineering applications by means of the FC approach [20-23]. FCs are synthetic measures of changes in the statistics of climate variables and can be derived also for characteristic values of climatic actions investigating the $n-$ th time window and the initial time window. The main assumption in the FC approach is that errors in measurements and predictions of climate variables are nearly constant over time. Of course, the higher the quality of the data the more reliable are the results obtained with the proposed method.

To be consistent with the actual definition of climatic hazard maps for structural design [6-8,58,59], a 40-year period is considered in the present study for the definition of the time windows and a time shift of 10 years between each other is adopted.

The fundamental steps of the procedure are the following:

1. Extraction of annual maxima of the investigated climate variable for the investigated time windows (e.g., 1951-1990, 1961-2000, 1971-2010, . . , 2050-2090);

2. Elaboration of extreme values for each time period, via the block maxima method [60]. Of course, several extreme value distributions can be assumed for the considered variable. Since ground snow load extremes in Europe are usually described by the extreme value type I (EVI) distribution $[31,33,36]$, an EVI distribution was assumed in the present study too. The cumulative distribution function (CDF) of the EVI distribution, also known as Gumbel distribution, is

$$
F(x<X)=\exp \left\{-\exp \left[-\left(\frac{x-\mu}{\sigma}\right)\right]\right\} \text { with } \mu \in \mathbb{R} ; \sigma>0,
$$

being $\mu$ the location, and $\sigma$ the scale of the distribution.

3. Characteristic values of ground snow load, $q_{k}(n)$, are thus evaluated for the $n$-th time window, from

$$
q_{k}(n)=\mu+\sigma \cdot\{-\ln [-\ln (1-p)]\} .
$$

In the equation, $p$ is the given probability of exceedance, i.e., $p=0.02$ in one year according to EN1990 [10].

4. FC are derived in terms of ratios between the characteristic value in the $n$-th time window and that obtained in the first one

$$
\mathrm{FC}(n)=\frac{q_{k}(n)}{q_{k}(n=1)} .
$$

FCs can provide advice for the update of climatic maps given in codes and standards, relying on the analysis of past observations. In this context, it is important to underline once more that engineering works shall cope with climatic hazards during their physical life, which can obviously be longer than the design service life [8]. Therefore, to guarantee adequate reliability levels over time for the designed structures, an adaptation strategy for structural design was proposed in [8], which consists of adopting an envelope of characteristic values in the future time windows for the updated climatic load maps $[8,59]$.

According to the proposed approach, the updated values of ground snow load $q_{k}^{\prime}$, including influence of climate change, are obtained multiplying the maximum FC in the future time windows by the current value of $q_{k}$ obtained from the analysis of observations $\left(q_{k, o b s}\right)$

$$
q_{k}=\max (\mathrm{FC}(t)) \cdot q_{k, o b s}
$$




\section{Results and Discussion}

\subsection{Climate Simulations for the Historical Period}

First, the capability of RCM ensemble to reproduce the observed climate was assessed, comparing the outcomes of historical simulations for the period 1951-2005, which are based on the measured atmospheric composition changes, with the available observations. Characteristic ground snow load maps were developed with this aim and illustrated in Figure 2.
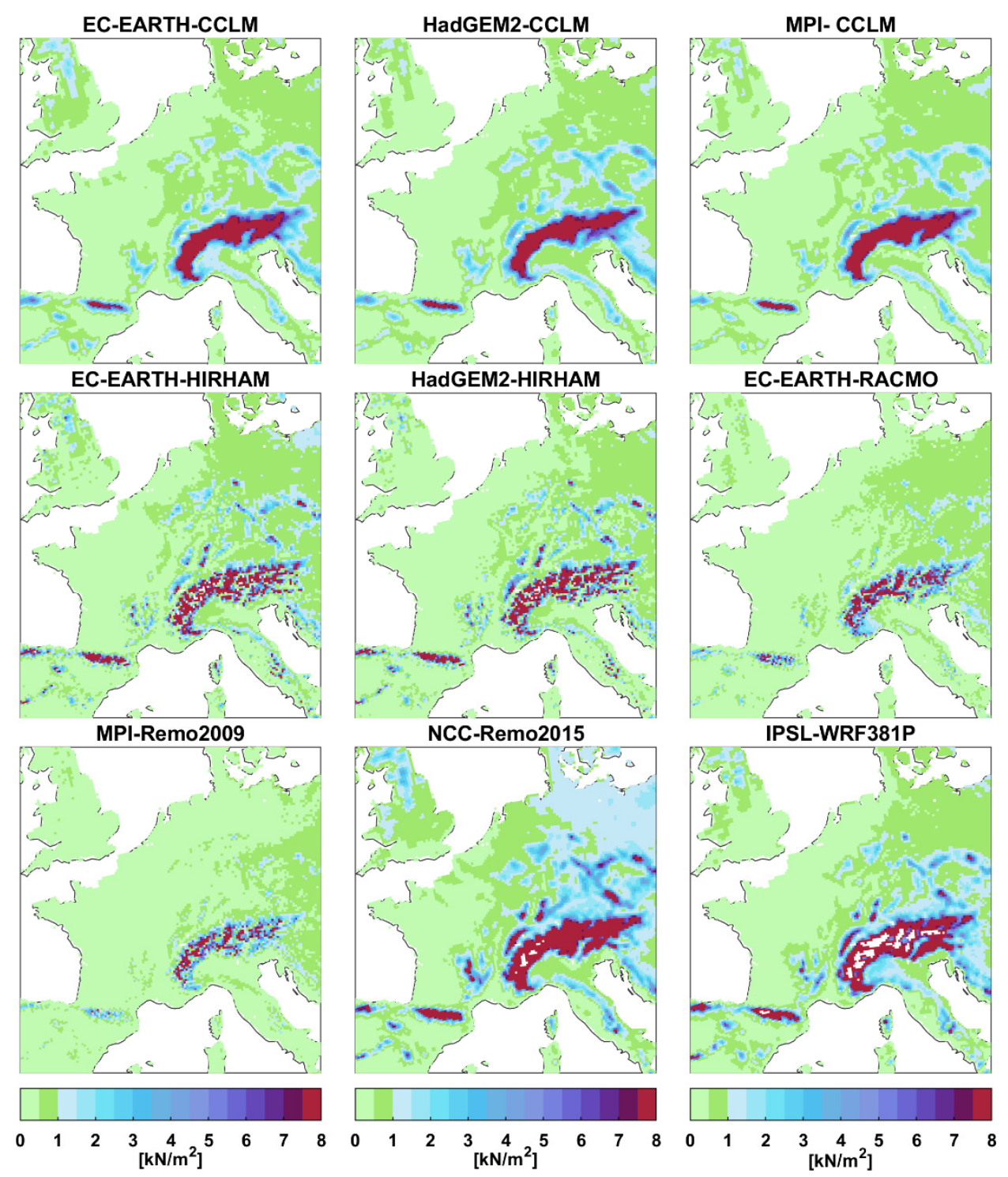

Figure 2. Characteristic ground snow load maps, showing load values associated to 0.02 probability of exceedance in one year, elaborated from the analysis of the nine climate models, described in Table 1, considering the period 1951-1990.

The maps in Figure 2 were developed extracting, for each considered GCM/RCM and for each cell in the EUR11 domain, the annual maxima in the period 1951-1990, by means of an extreme value analysis, fitting an EVI distribution. White areas in the maps in Figure 2 represent cells characterized by unrealistic snow accumulation (SWE $>70 \mathrm{kN} / \mathrm{m}^{2}$ ), which were disregarded in the analysis according to the already mentioned criterion.

The reference ground snow load map, derived for each climate region from the analysis of observations covering the same period [33] during the ESLRP, and reported in EN1991-1-3 Annex C (Figure 3a) was compared with the snow load map derived according 
to the Climate Models Ensemble mean (Figure 3b), in terms of differences of characteristic values (Figure 3c). To be consistent with EN1991-1-3 provisions, cells characterized by altitude higher than $1500 \mathrm{~m}$ are not represented in Figure 3.



(a)

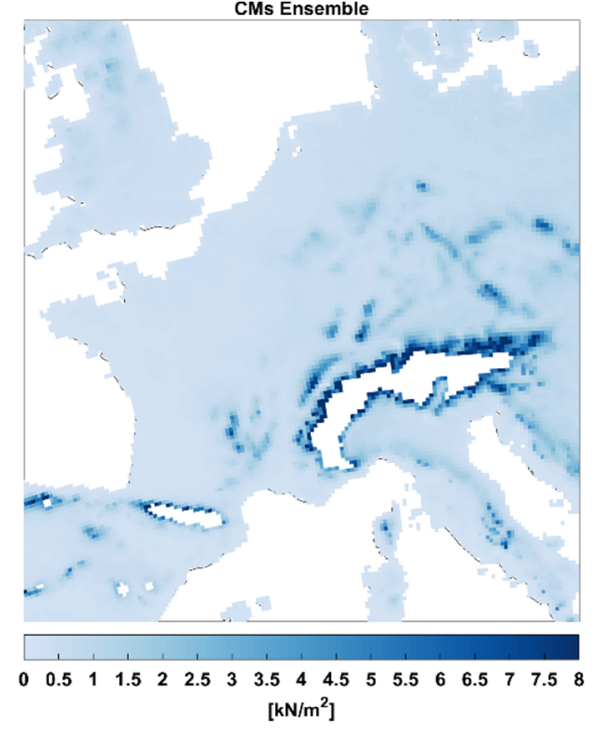

(b)

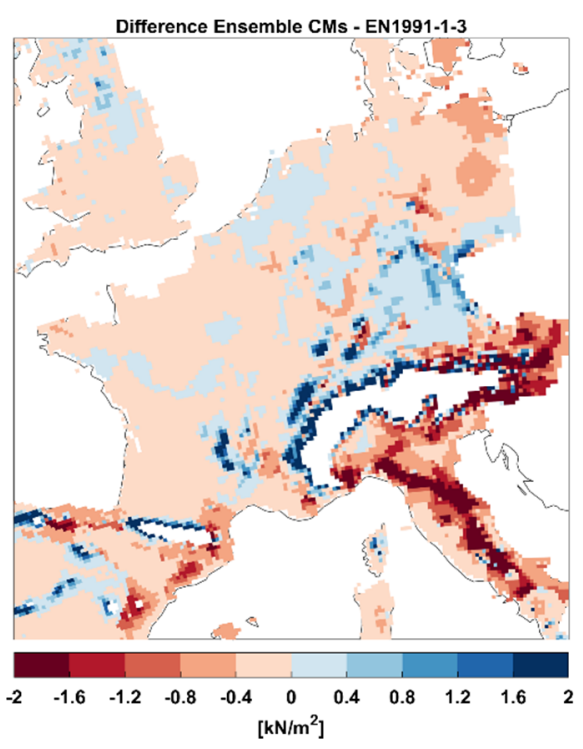

(c)

Figure 3. Characteristic ground snow load maps as provided in EN1991-1-3:2003 (a) and derived according to the Climate Models Ensemble mean (b), difference map between CMs ensemble and EN1991-1-3:2003 (c) for the period 1951-1990.

The reference map in Figure 3a was obtained considering the altitude of the cell of the climate model and the snow load-altitude relationship provided in EN1991-1-3:2003 [34] for the corresponding climatic regions.

Error statistics (root-mean-square error, RMSE, and mean absolute error, MAE) were evaluated considering characteristic load values obtained from RCMs simulations over the period 1951-1990 (ensemble mean) and the reference values obtained from the analysis of measurements in ESLRP for the different climatic regions defined in [33,34], shown in Figure 1. Error statistics were thus computed for each cell in the climatic region (Alpine, Mediterranean, Central East, Central West, Iberian Peninsula, UK and Eire) comparing snow loads given by the RCMs and EN provisions. Error values were then averaged for cells belonging to the same region and reported in Table 2.

Table 2. RMSE and MAE statistics between RCMs ensemble mean and EN1991-1-3:2003 ground snow load map.

\begin{tabular}{ccc}
\hline Climatic Region & RMSE $\left(\mathbf{k N} / \mathbf{m}^{\mathbf{2}}\right)$ & MAE $\left(\mathbf{k N} / \mathbf{m}^{\mathbf{2}}\right)$ \\
\hline Alpine & 2.43 & 1.44 \\
Mediterranean & 1.10 & 0.73 \\
Central East & 0.39 & 0.30 \\
Central West & 0.32 & 0.16 \\
Iberian Peninsula & 0.83 & 0.34 \\
UK-Eire & 0.36 & 0.17 \\
\hline
\end{tabular}

RMSE values range from 0.32 (Central West) to $2.43 \mathrm{kN} / \mathrm{m}^{2}$ (Alpine) and highlight significant errors especially for the Alpine, Mediterranean and Iberian regions. Differences in error magnitude can be motivated by the different orographic features. In fact, the considerable smoothing of surface orography in RCMs, associated to cell dimension, leads to higher errors in orographically structured terrain [27], while regions characterized with small orography variability show a better performance. Moreover, higher snow loads are 
associated to high altitude regions and consequently higher absolute errors are obtained for regions such as the Alps.

The detected errors suggest the adoption of a calibration strategy to analyze climate projections of snow water equivalent. The FC approach is an efficient methodology, commonly used in climate impact research [20]. As described before, changes can be derived comparing future and current climate simulations provided by RCMs and then applied to observed values at local scale to estimate modeled future values. In this way, it is assumed that the ensemble of climate simulations is particularly effective in detecting changes in the statistics of climate variables over time [54]. In Section 3.3, the ability of the investigated RCM ensemble to detect changes for the observation period (1951-2020) will be evaluated at selected weather stations.

\subsection{Future Climate Projections}

In this section, climate projections provided by the nine climate models described in Table 1 are analyzed to assess future changes in characteristic ground snow loads depending on the RCP4.5 and RCP8.5 scenarios. With this objective, consecutive time windows of 40 years, shifted 10 years from each other, are considered from 1950 to 2090, i.e., (1951-1990, 1961-2000, 1971-2010, ... , 2050-2090).

Ensemble mean FC maps referring to three time windows (1971-2010, 1991-2030 and 2011-2050) are illustrated in Figures 4 and 5, for two scenarios RCP4.5 and RCP8.5, respectively. These maps show the regional variability of the expected future trends across Europe. A general decreasing trend is obtained for most of Europe, but there are still areas characterized by constant or increasing trend in the future.

The statistical significance of the expected changes was evaluated performing a twosample Kolmogorov-Smirnov (K-S) test, for the distribution of annual maxima in the moving time windows at each cell. A 5\% significance level was considered, and dots were added in the maps at cells where changes are statistically significant for the K-S test according to the majority of the investigated climate models. Although in the first time windows statistical significance is observed in few regions, it substantially increases moving far into the future; in fact, almost the whole EUR-11 domain is characterized by statistically significant changes if the time window 2011-2050 is considered (see Figures 4 and 5).

In Figures 4 and 5, ensemble mean values of FC computed for each cell in the EUR11 domain are shown, however, an explicit evaluation of uncertainty among the different simulations is needed to ensure robust climate adaptation strategies [61]. A first assessment of the uncertainty in the detected changes was carried out considering the variability of different climate change projections. The agreement among each of the $18(2 \mathrm{RCPs} \times 9 \mathrm{RCMs})$ alternative climate projections was evaluated following the procedure illustrated in [61]. FC were classified for all grid cells into four quartiles and an integer value of 1 (lower quartile) to 4 (upper quartile) was assigned to each quartile. The quartile assignment was done separately for each of the 18 simulations, then, for each grid cell, the most frequent quartile value assigned to each grid cell (i.e., the mode) was identified together with the frequency of the mode (i.e., the number of occurrences of the mode). When all 18 simulations are available for the investigated grid cell, the frequency of the mode ranges from 5 (no agreement among simulations) to 18 (perfect agreement). This parameter represents an index of the agreement among different models and scenarios; moreover, its complement to 18 can indirectly provide a rough quantification of the uncertainty of the projections. 

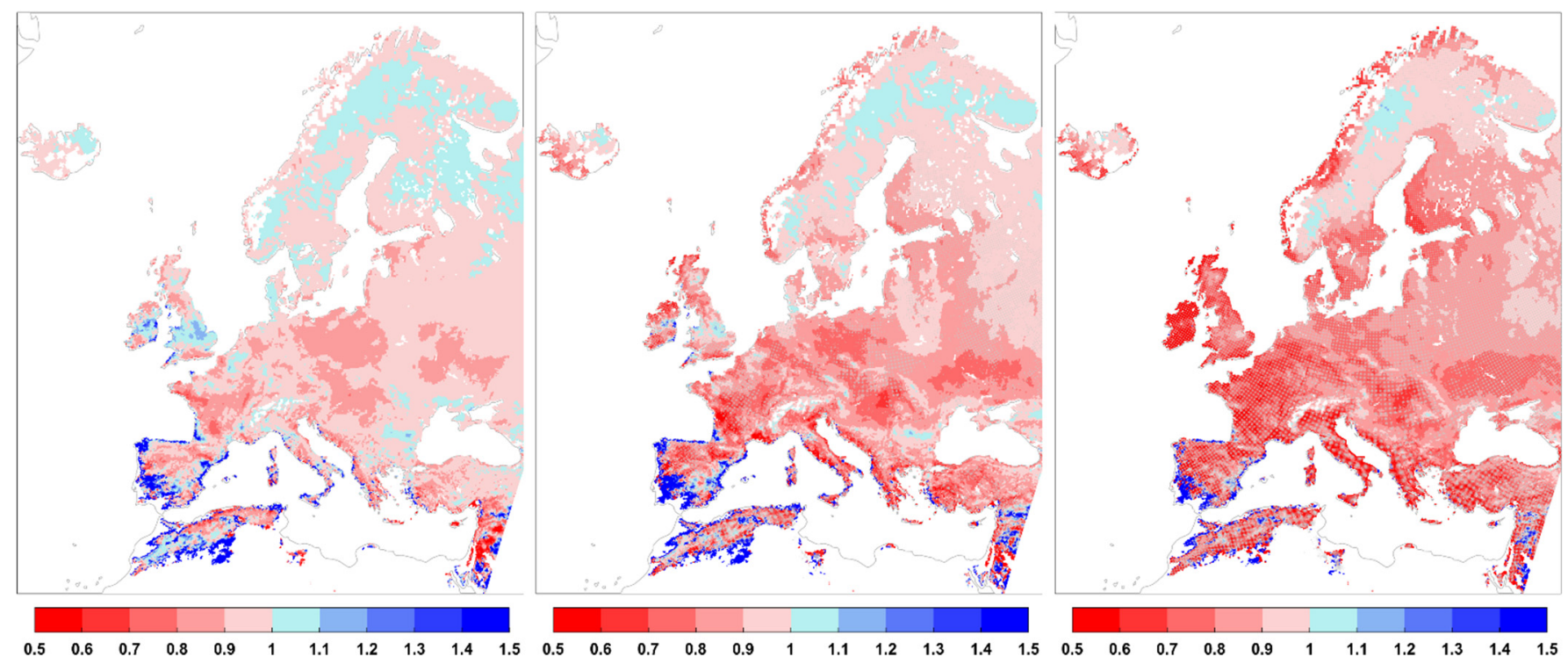

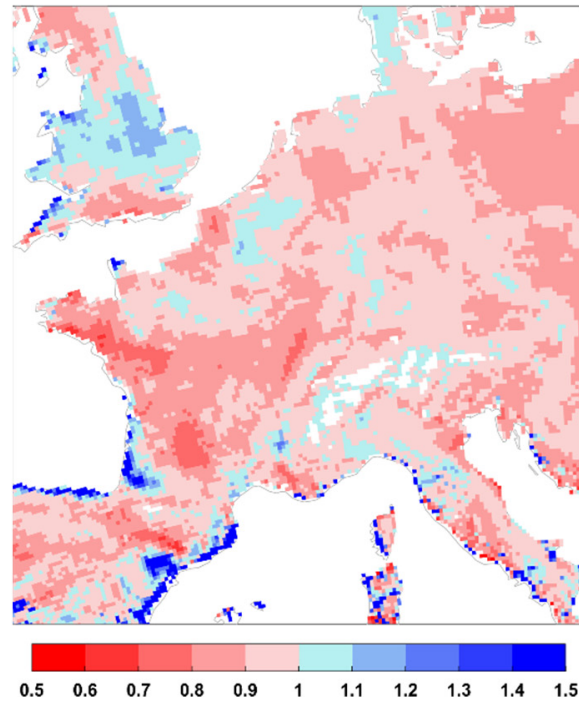

(a)

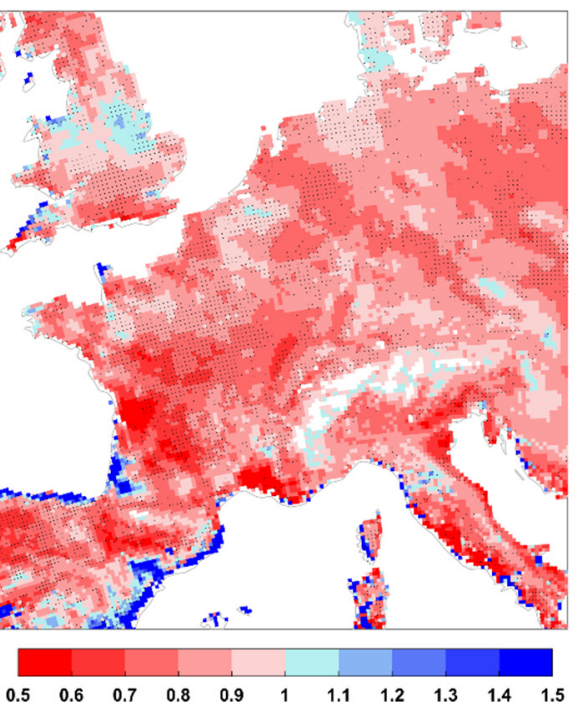

(b)

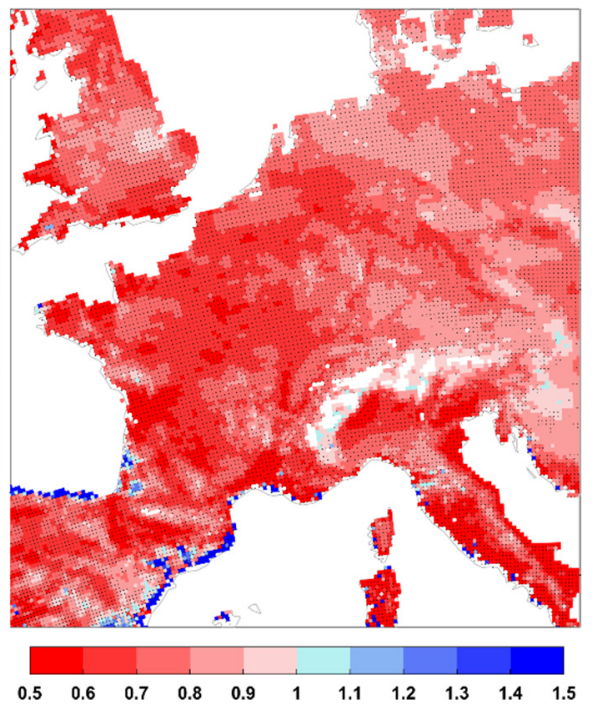

(c)

Figure 4. FC maps (ensemble mean) for characteristic ground snow loads, associated to 0.02 probability of exceedance in one year, in the Euro-Cordex domain (first row) and a focus on central Europe (second row). Three moving time windows are considered (1971-2010 (a), 1991-2030 (b), and 2011-2050 (c)) in the elaboration with respect to 1951-1990, based on RCP4.5 scenario. The dots indicate statistically significant changes in the distribution of annual maxima at the 5\% level.

The results are shown in terms of mode and frequency of the mode for FCs in the time window 2011-2050 with respect to 1951-1990, in Figure 6a,b, respectively. The mode of quartile (Figure 6a) shows the most frequent quartile value associated with each grid cell. For example, in a large part of the Scandinavian region (red areas) the mode is equal to four (fourth quartile), corresponding to higher FC values. In the same areas, a high frequency of the mode value is obtained, therefore a high level of agreement is achieved among the investigated ensemble members (blue areas in Figure 6b). 

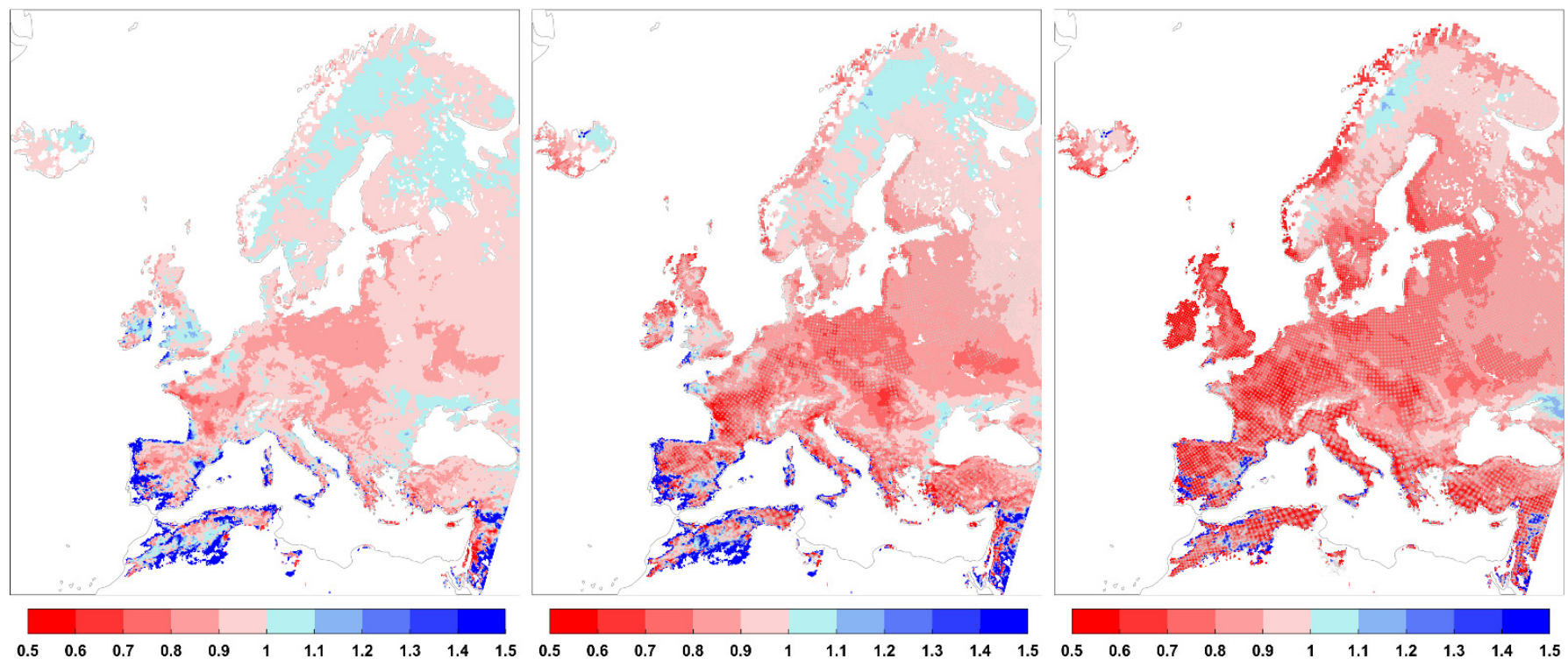

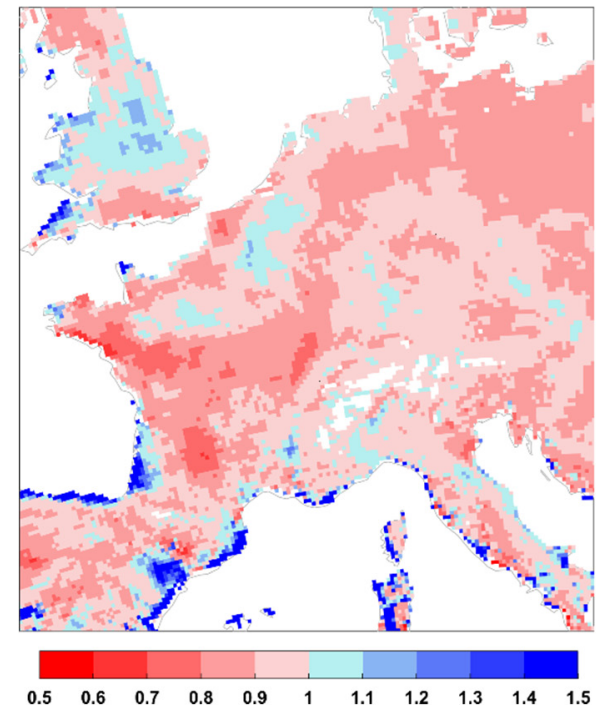

(a)



(b)

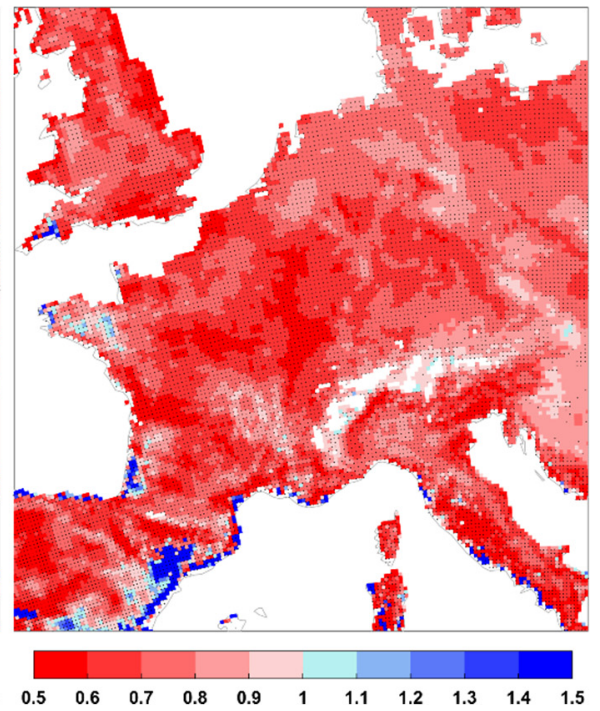

(c)

Figure 5. FC maps (ensemble mean) for characteristic ground snow loads, associated to 0.02 probability of exceedance in one year, in the Euro-Cordex domain (first row) and a focus on central Europe (second row). Three moving time windows are considered (1971-2010 (a), 1991-2030 (b), and 2011-2050 (c)) in the elaboration with respect to 1951-1990, based on RCP8.5 scenario. The dots indicate statistically significant changes in the distribution of annual maxima at the 5\% level.

The level of agreement among climate simulations varies on the investigated territory. Looking at the histogram of the frequency of the mode in Figure 6b: an agreement is obtained ( $\geq 10$ of 18 ) for $52 \%$ of the EUR-11 domain, higher frequency values ( $\geq 16$ of 18 ) are obtained in $7 \%$ of the domain, while full agreement among the simulations occurred in $3 \%$ of the grid cells.

In Figure 7, the envelope of FC is illustrated for the two considered emission scenarios. For each cell of the EUR-11 domain, the maximum value of FC in the moving time windows $t$ is shown. 




(a)
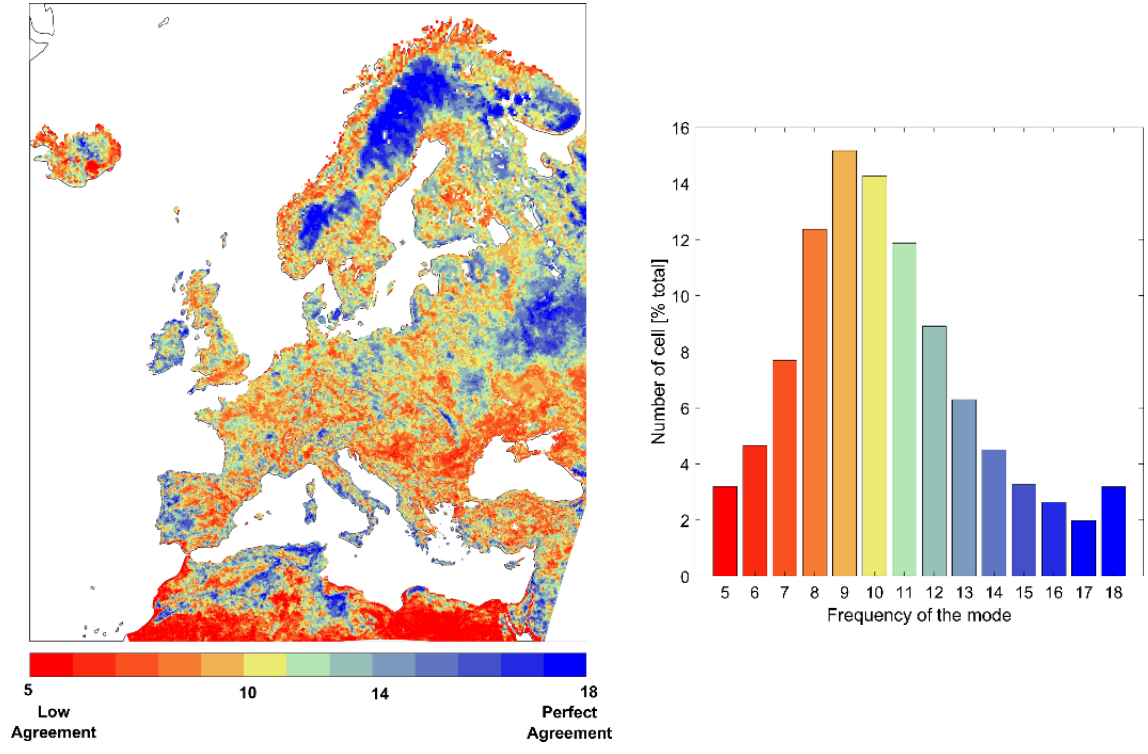

(b)

Figure 6. Mode of quartile (a) and frequency of the mode map and histogram (b) among the 18 different projections of expected changes in characteristic ground snow loads in the time window 2011-2050 with respect to 1951-1990. In (b) red areas in the map indicate lower intermodel agreement and higher uncertainty while blue areas indicate higher agreement and lower uncertainty. The histogram is drawn for the frequency of the mode considering the number of cells as $\%$ of the total in the EUR-11 domain.

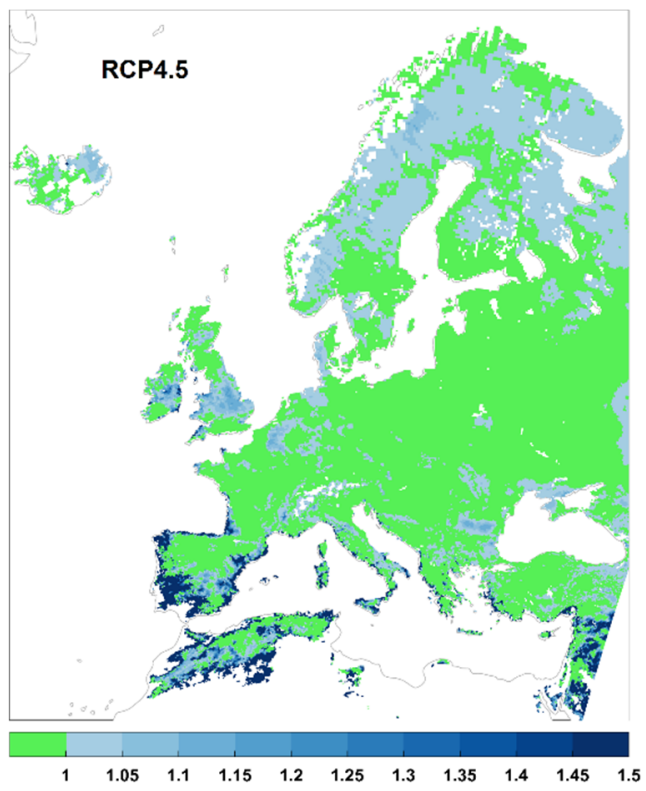

(a)

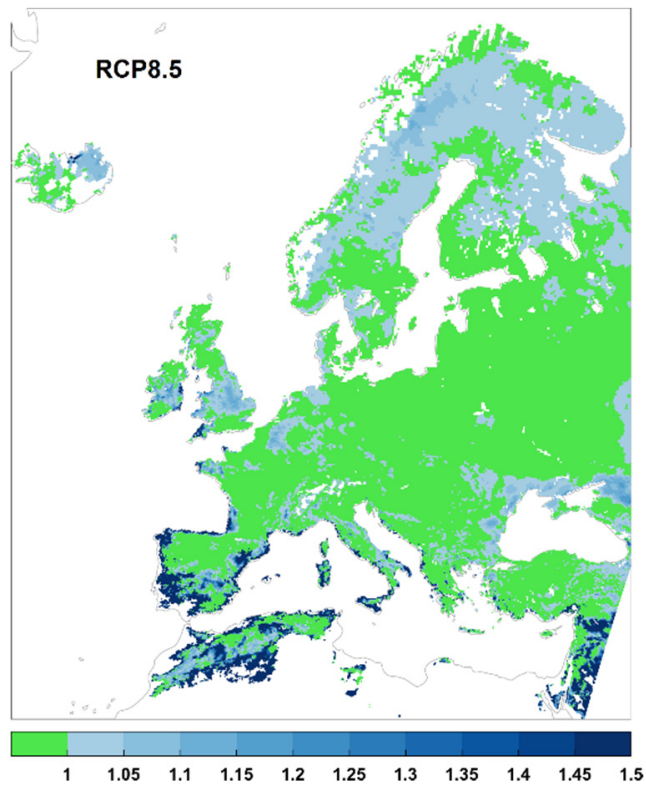

(b)

Figure 7. FC envelope maps for characteristic ground snow loads according to the RCP4.5 (a) and RCP8.5 (b). For each cell of the EUR-11 domain, the maximum value of FC in the moving time windows is shown.

Green areas show zones where the update of characteristic values is not needed $(\max (\mathrm{FC}) \leq 1)$ while in the blue colored areas an increase is expected $(\max (\mathrm{FC})>1)$ according to the investigated climate ensemble and an update of the reference value of ground snow load would be recommended. In fact, an adaptation of design load is needed when an increase of the load is expected for the future to guarantee that structure designed now will be able to withstand future changes. In case of expected decreasing trend, no 
adaptation is necessary since structure should be designed according to the current value of the load which can be experienced by the structure during the first years of its service.

FC values higher than one are obtained for UK, Norway and Sweden, but the most significant FC values result for the southern part of the French Atlantic coast, for the Iberian Peninsula, and Mediterranean coastal areas where few snow events are however experienced.

\subsection{Evaluation of Current and Future Trends at Selected Weather Stations}

A first comparison against point observations was carried out to assess the ability of climate projections to reproduce current and past trends. To the aims of the present study, 42 weathers station in Germany and Switzerland, characterized by a high-quality data series of snow measurements in the period 1951-2020, were considered (see Figure 8).

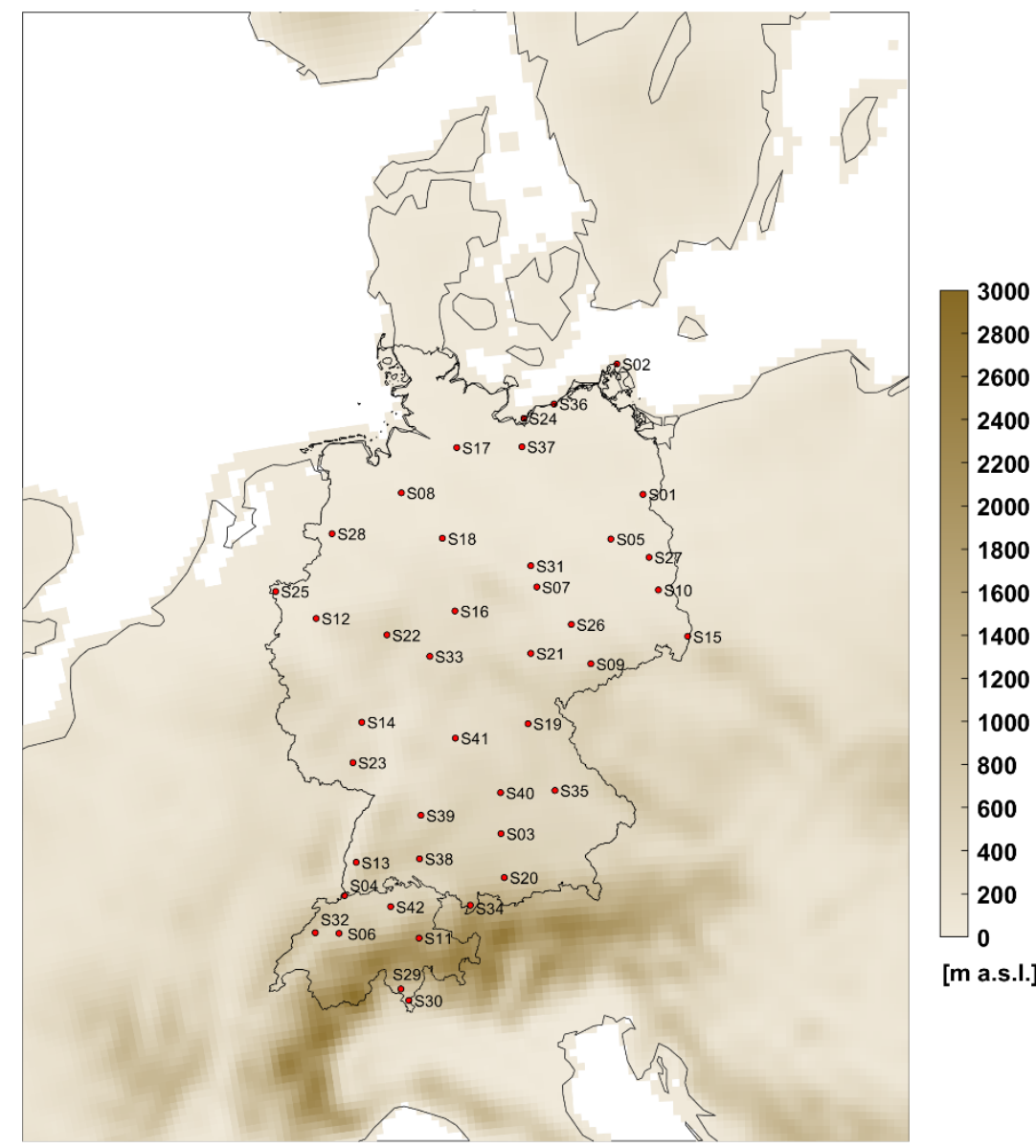

Figure 8. Elevation map and geographical locations of the 42 weather stations in Table 3.

Obviously, to obtain a general assessment for the whole European territory, more uniformly distributed weather stations should be considered. However, this is not an easy task since snow data are still poorly documented and long series of high-quality data, from which trend can be evaluated, are available for few countries in Europe [62]. Moreover, the number of reliable weather station can vary from site to site, so that the coverage of various areas is non-uniform. 
Table 3. Comparison of FC of $q_{k}$ in the time window 1981-2020 with respect to 1951-1990 obtained from the RCMs ensemble and the observations.

\begin{tabular}{|c|c|c|c|c|c|c|}
\hline $\begin{array}{l}\text { Station } \\
\text { Id. }\end{array}$ & Station & $\begin{array}{c}\text { Lon } \\
{\left[{ }^{\circ}\right]}\end{array}$ & $\begin{array}{l}\text { Lat } \\
{\left[{ }^{\circ}\right]}\end{array}$ & $\begin{array}{l}\text { Alt. } \\
{[\mathrm{m}]}\end{array}$ & $\begin{array}{c}\text { FC } \\
\text { Obs. }\end{array}$ & $\begin{array}{c}\text { FC } \\
\text { Ensemble Mean }\end{array}$ \\
\hline S01 & Angermünde & 13.99 & 53.03 & 54 & 0.72 & 0.81 \\
\hline S02 & Arkona & 13.43 & 54.68 & 42 & 1.01 & 0.94 \\
\hline $\mathrm{S} 03$ & Augsburg & 10.94 & 48.43 & 462 & 0.61 & 0.81 \\
\hline S04 & Basel & 7.58 & 47.54 & 316 & 1.09 & 0.79 \\
\hline S05 & Berlin-Dahlem (FU) & 13.30 & 52.45 & 51 & 0.79 & 0.78 \\
\hline S06 & Bern & 7.46 & 46.99 & 553 & 0.86 & 0.86 \\
\hline S07 & Bernburg/Saale & 11.71 & 51.82 & 85 & 0.84 & 0.94 \\
\hline S08 & Bremen & 8.80 & 53.05 & 4 & 0.68 & 0.90 \\
\hline S09 & Chemnitz & 12.87 & 50.79 & 418 & 1.10 & 0.90 \\
\hline S10 & Cottbus & 14.32 & 51.78 & 69 & 0.72 & 0.82 \\
\hline S11 & Elm & 9.18 & 46.92 & 958 & 0.80 & 0.92 \\
\hline $\mathrm{S} 12$ & Essen-Bredeney & 6.97 & 51.40 & 150 & 0.87 & 0.69 \\
\hline $\mathrm{S} 13$ & Freiburg & 7.83 & 48.02 & 237 & 0.68 & 0.75 \\
\hline S14 & Geisenheim & 7.95 & 49.99 & 110 & 0.88 & 0.94 \\
\hline S15 & Görlitz & 14.95 & 51.16 & 238 & 0.94 & 0.86 \\
\hline S16 & Göttingen & 9.95 & 51.50 & 167 & 0.82 & 0.79 \\
\hline S17 & Hamburg-Fuhlsbüttel & 9.99 & 53.63 & 14 & 0.77 & 0.85 \\
\hline $\mathrm{S} 18$ & Hannover & 9.68 & 52.46 & 59 & 0.78 & 0.90 \\
\hline S19 & Heinersreuth-Vollhof & 11.52 & 49.97 & 350 & 1.01 & 0.80 \\
\hline S20 & Hohenpeißenberg & 11.01 & 47.80 & 977 & 0.87 & 0.86 \\
\hline S21 & Jena (Sternwarte) & 11.58 & 50.93 & 155 & 0.87 & 0.93 \\
\hline $\mathrm{S} 22$ & Kahler-Asten & 8.49 & 51.18 & 839 & 0.79 & 0.80 \\
\hline S23 & Kaiserslautern & 7.76 & 49.43 & 271 & 0.64 & 0.78 \\
\hline S24 & Kirchdorf/Poel & 11.43 & 54.00 & 12 & 0.93 & 0.86 \\
\hline S25 & Kleve & 6.10 & 51.76 & 46 & 0.74 & 0.82 \\
\hline S26 & Leipzig-Holzhausen & 12.45 & 51.32 & 138 & 0.73 & 0.90 \\
\hline S27 & Lindenberg & 14.12 & 52.21 & 98 & 0.79 & 0.83 \\
\hline S28 & Lingen & 7.31 & 52.52 & 22 & 0.67 & 0.76 \\
\hline S29 & Locarno & 8.79 & 46.17 & 367 & 0.82 & 0.77 \\
\hline S30 & Lugano & 8.96 & 46.00 & 273 & 1.05 & 0.74 \\
\hline S31 & Magdeburg & 11.58 & 52.10 & 79 & 0.65 & 0.88 \\
\hline S32 & Neuchotel & 6.95 & 47.00 & 485 & 0.76 & 0.91 \\
\hline S33 & Neukirchen-Hauptschwenda & 9.41 & 50.89 & 500 & 0.79 & 0.77 \\
\hline S34 & Oberstdorf & 10.28 & 47.40 & 806 & 0.84 & 1.00 \\
\hline S35 & Regensburg & 12.10 & 49.04 & 365 & 0.96 & 0.81 \\
\hline S36 & Rostock-Warnemünde & 12.08 & 54.18 & 4 & 0.88 & 0.83 \\
\hline S37 & Schwerin & 11.39 & 53.64 & 59 & 0.97 & 0.82 \\
\hline S38 & Sigmaringen-Laiz & 9.19 & 48.07 & 581 & 0.80 & 0.76 \\
\hline S39 & Stuttgart-Echterdingen & 9.22 & 48.69 & 371 & 0.72 & 0.83 \\
\hline $\mathrm{S} 40$ & Weißenburg-Emetzheim & 10.93 & 49.01 & 439 & 0.80 & 0.79 \\
\hline S41 & Würzburg & 9.96 & 49.77 & 268 & 1.01 & 0.90 \\
\hline $\mathrm{S} 42$ & Zurich & 8.57 & 47.38 & 556 & 0.91 & 0.76 \\
\hline
\end{tabular}

FC were evaluated at the selected weather stations for characteristic values of ground snow loads $q_{k}$, mean of annual maxima $\bar{Q}$ and the coefficient of variation of annual maxima $\mathrm{COV}_{Q}$ for the available time windows in the observation period (1951-1990, 1961-2000, 1971-2010 and 1981-2020). Results are summarized in Figure 9 for FC of $q_{k}$, in Figure 10a for FC of $\bar{Q}$ and in Figure 10b for FC of $\mathrm{COV}_{Q}$, considering the average $\mu$ and the confidence interval $\mu \pm 1.645 \sigma$. Observed trends (in red) were compared against those obtained by climate projections for the corresponding cells for the historical and future period (in blue and in green for the RCP4.5 and 8.5, respectively). 


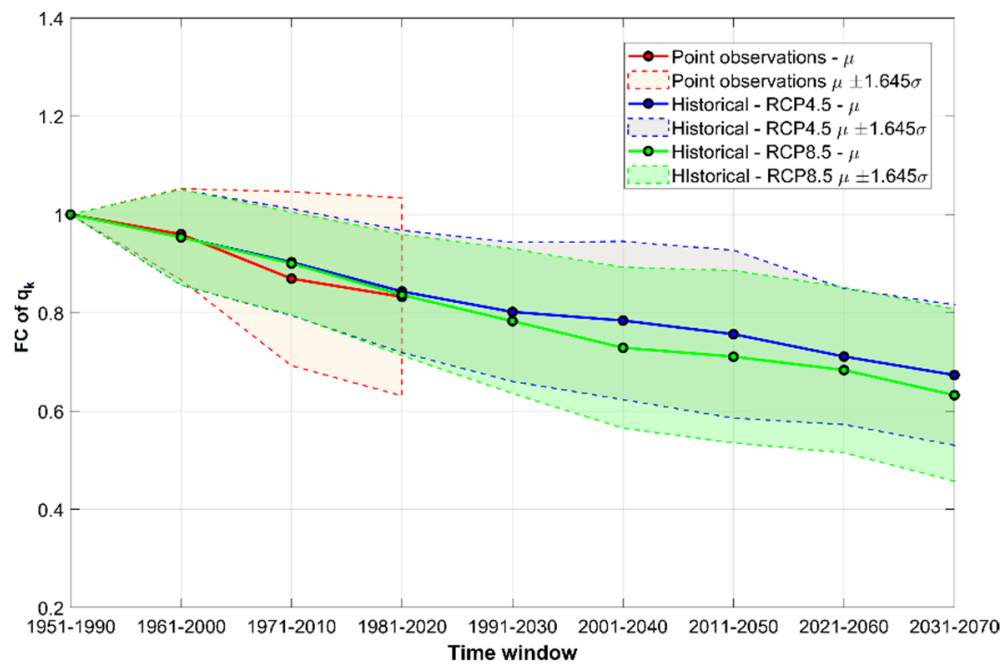

Figure 9. FC of characteristic values of ground snow load $q_{k}$, associated to 0.02 probability of exceedance in one year, for the investigated weather stations. Average value $\mu$ and confidence interval $\mu \pm 1.645 \sigma$ are shown according to point observations (in red) and regional climate model projections depending on the scenario RCP4.5 (in blue) and RCP8.5 (in green).

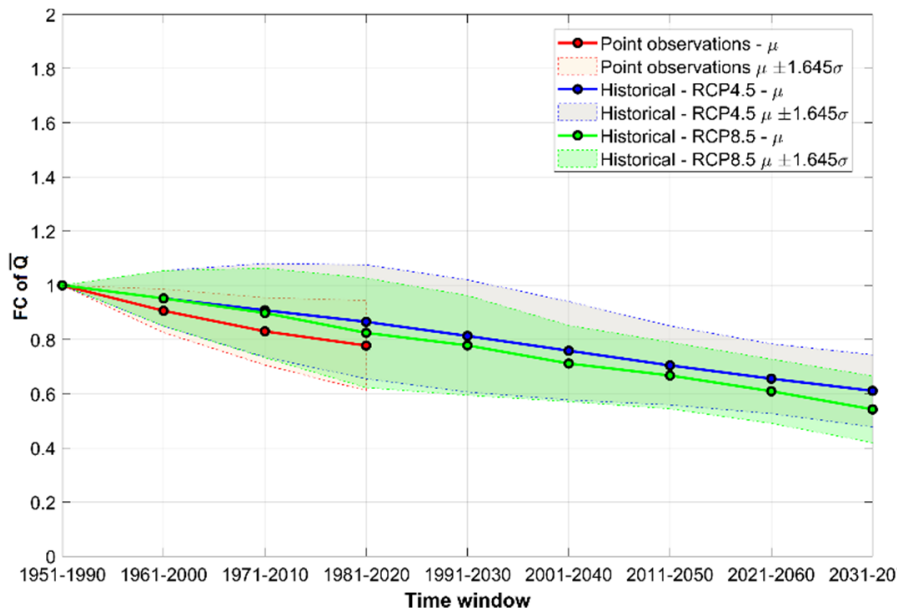

(a)

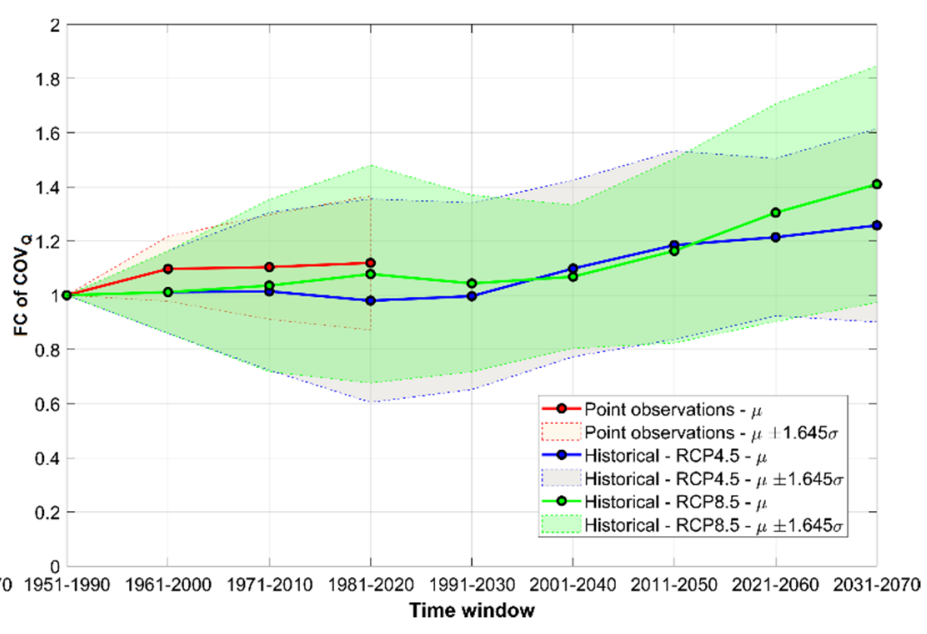

(b)

Figure 10. FC of mean annual maxima ground snow load $\bar{Q}(\mathbf{a})$ and FC of coefficient of variation of annual maxima ground snow load $\mathrm{COV}_{Q}$ (b), for the investigated weather stations. Average value $\mu$ and confidence interval $\mu \pm 1.645 \sigma$ are shown according to point observations (in red) and regional climate model projections depending on the scenario RCP4.5 (in blue) and RCP8.5 (in green).

In Table 3, results for single stations are reported for the FCs of $q_{k}$ in the time window 1981-2020.

It is important to highlight that observations and predictions give similar trends for the study area, in particular, the decreasing tendency in characteristic values of ground snow load predicted by the projections matches the observations. This decreasing trend for the investigated area is the result of a significant reduction of the mean value of annual maxima $\bar{Q}$ which is combined with a contrasting increase in variability $\left(\mathrm{COV}_{Q}\right)$, and it is consistent with the theory illustrated by O'Gorman in [38] about the contrasting responses of mean and extreme snowfall to climate change. The increase in variability is often combined with an increase in the skewness of the distribution.

It is important to recall that extreme events in a changing climate are much more sensitive to changes in the variability than on averages as first demonstrated by Katz and Brown in [63] and this sensitivity is relatively greater the more extreme the event. In fact, 
the increase in variability, which is confirmed by the observations and expected to be even more relevant for the future, may have a significant impact in the long-term structural reliability. For example, in [25] the assessment of variations in structural reliability over time is discussed, starting from the expected changes in mean and COV of annual maxima.

Error statistics (root-mean-square error, RMSE) between FC obtained from the RCMs ensemble and the point observations are reported in Table 4 considering the whole investigated area (RMSE in regional average) and the single stations (mean of RMSE for the single stations). RMSE were computed for $q_{k}$, mean of annual maxima $\bar{Q}$ and coefficient of variation of annual maxima $\mathrm{COV}_{Q}$ considering the two different emission scenarios. It is important to recall that the simulation period for the RCP scenarios starts from 2006.

Table 4. RMSE statistics between FC obtained from the RCMs ensemble and the point measurements for the investigated weather stations.

\begin{tabular}{cccc}
\hline Scenario & Parameter & RMSE Regional Average & RMSE Single Stations Average \\
\hline \multirow{2}{*}{ RCP4.5 } & $q_{k}$ & 0.021 & 0.113 \\
& $\bar{Q}$ & 0.073 & 0.150 \\
& $\operatorname{COV}_{Q}$ & 0.108 & 0.239 \\
\hline \multirow{2}{*}{$\mathrm{RCP} 8.5$} & $q_{k}$ & 0.018 & 0.108 \\
& $\bar{Q}$ & 0.055 & 0.139 \\
& $\mathrm{COV}_{Q}$ & 0.068 & 0.228 \\
\hline
\end{tabular}

Results confirm the capability of the ensemble to adequately reproduce regional trends for the investigated parameters, as it was already observed in Figures 9 and 10. Clearly, higher errors were obtained considering FC for individual weather stations. It can be also noticed that the scenario RCP8.5, which is characterized by lower errors than RCP4.5, seems to better capture trends up to now.

\section{Conclusions}

The estimate of the evolution of extreme snow loads in a changing climate is a crucial issue for structural design of roofs. In fact, even in a warmer climate, the relevance of snow induced collapses is confirmed by the negative impacts of recent heavy snowfall events, which took place in various European countries. In this context, the current assumption of stationary climate for the statistical elaboration of historical extreme values of climatic actions, is becoming controversial due to the impacts of climate change, that are calling for the set-up of suitable adaptation strategies for a climate resilient structural design.

In the paper, changes in extreme ground snow loads in Europe from 1951 to 2100, were estimated considering an ensemble of high-resolution projections, recently provided by EURO-CORDEX. Maps obtained from climate model simulations for the historical period were compared against maps based on observations, showing a general snow load underestimation by the RCMs. This general underestimation was expected and can be motivated by the gap between the scale of observations and of climate models, even at the finest available resolution. In fact, the smoothing of surface topography in RCMs and the consequent orography mismatch between RCMs grid and weather stations may lead to significant biases in snow loads, especially in orographically structured terrain.

In the author's opinion, this issue can be considerably mitigated when the evolution of snow loads is described focusing on factors of change, rather than on absolute load values. In fact, the adoption of a calibration strategy based on the FC approach, seems to be very effective to overcome this problem, allowing a satisfactory estimate of the evolution over time of snow loads at the scale of observations.

Consistently with the current techniques adopted to derive climatic load maps based on observations, FC maps are derived considering consecutive time windows of 40 years, shifted 10 years from each other. FC maps are an easy to use representation of climate change signals to adapt load maps in codes and standards [58,59], as well as to assess variations in structural reliability over time under non-stationary loads [25]. In addition, 
uncertainty in the FC maps can be evaluated considering the variability in climate change projections too. The satisfactory agreement achieved in large areas of the European domain demonstrates that these maps can be a useful tool for planning of conservation and adaptation strategies. Moreover, the comparison of the outcomes of the procedure with the analysis of high-quality point observations at selected weather stations in Switzerland and Germany for the period 1951-2020, confirms the capability of the multi-model ensemble to reproduce historical trends of extreme snow loads on ground in that area. The investigated stations show a general decrease of characteristic values: this is the result of a significant decrease of mean annual maxima, however associated with an increased variability of the action. Such increased variability, combined with the inherent uncertainty of climate models and scenarios, should be duly considered in the assessment of long-term structural reliability and suggests the implementation of suitable adaptation measures in the definition of design loads, aiming to maintain the required target reliability of the structure during its whole real life [25].

An example of FC map is given at European scale in Figure 7, where regions are identified, in which it results FC $>1$ and increases of reference values of snow load for structural design are expected in the future. FC values higher than one are obtained for UK, Norway and Sweden, but the most significant changes affect the southern part of the French Atlantic coast, the Iberian Peninsula, and the Mediterranean coastal areas. Both RCP scenarios lead to similar FC maximum values; exceptions are found in some limited regions located for example in south-west England (Cornwall and Devon), north-Iceland, north-Scandinavia, south-Spain and east-Romania.

In the highlighted regions, an adaptation is needed, especially for design of lightweight roof structures, considering both the FC value given by the map and the current load value given by the structural Code. It must be stressed that the FC values obtained according to the illustrated procedure are consistently referred to the elaboration of available data, in terms of climate projections and observations. Therefore, they should be critically reviewed and handled since they disregard possible safe-sided assumptions, or inherent additional safety provisions, which could be already implemented in the current structural Code maps.

Author Contributions: Conceptualization, P.C., P.F. and F.L.; methodology, P.C., P.F. and F.L.; software, P.C., P.F. and F.L.; validation, P.C., P.F. and F.L.; formal analysis, P.C., P.F. and F.L.; investigation, P.C., P.F. and F.L.; resources, P.C.; data curation, P.C., P.F. and F.L.; writing—original draft preparation, P.C., P.F. and F.L.; writing-review and editing, P.C., P.F. and F.L.; visualization, P.C., P.F. and F.L.; supervision, P.C.; project administration, P.C.; funding acquisition, P.C. All authors have read and agreed to the published version of the manuscript.

Funding: This research received no external funding.

Institutional Review Board Statement: Not applicable.

Informed Consent Statement: Not applicable.

Data Availability Statement: The data presented in this study are available on request from the corresponding author. The data are not publicly available as they cannot be used for commercial purposes.

Acknowledgments: The authors acknowledge the World Climate Research Working Groups on Regional Climate, and on Coupled Modelling. The authors thank the climate modelling groups, recalled in Table 1, for providing the model outcomes via the infrastructure of the Earth System Grid Federation. The authors also acknowledge the Deutscher Wetterdienst (DWD) Climate Data Center and the MeteoSwiss for making available daily series of snow data.

Conflicts of Interest: The authors declare no conflict of interest. 


\section{References}

1. European Environmental Agency (EEA). Climate Change Impacts and Vulnerability in Europe-An Indicator-Based Report; EEA Report 1/2017; European Environment Agency: Copenhagen, Denmark, 2017.

2. Intergovernmental Panel on Climate Change (IPCC). Climate Change 2013: The Physical Science Basis; Contribution of Working Group I to the Fifth Assessment Report of the Intergovernmental Panel on Climate Change; Cambridge University Press: New York, NY, USA, 2013.

3. Intergovernmental Panel on Climate Change (IPCC). Climate Change 2014: Impacts, Adaptation And Vulnerability—Part B: Regional Aspects; Contribution of Working Group II to the Fifth Assessment Report of the Intergovernmental Panel on Climate Change; Cambridge University Press: Cambridge, UK, 2014.

4. Fischer, E.M.; Knutti, R. Observed heavy precipitation increase confirms theory and early models. Nat. Clim. Chang. 2016, 6, 986-991. [CrossRef]

5. European Environmental Agency (EEA). Climate Change Adaptation and Disaster Risk Reduction in Europe; EEA Report 15/2017; European Environment Agency: Copenhagen, Denmark, 2017.

6. Croce, P.; Formichi, P.; Landi, F.; Marsili, F. Climate change: Impact on snow loads on structures. Cold Reg. Sci. Technol. 2018, 150, 35-50. [CrossRef]

7. Croce, P.; Formichi, P.; Landi, F.; Mercogliano, P.; Bucchignani, E.; Dosio, A.; Dimova, S. The snow load in Europe and the climate change. Clim. Risk Manag. 2018, 20, 138-154. [CrossRef]

8. Croce, P.; Formichi, P.; Landi, F. Climate change: Impacts on climatic actions and structural reliability. Appl. Sci. 2019, 9, 5416. [CrossRef]

9. Madsen, H.O. Managing structural safety and reliability in adaptation to climate change. In Safety, Reliability, Risk and Life-Cycle Performance of Structures and Infrastructure; Deodatis, E.F., Ed.; Taylor \& Francis Group: London, UK, 2013; pp. 81-88. ISBN 978-1-315-88488-2.

10. European Committee for Standardization (CEN). EN 1990 Eurocode—Basis of Structural Design; CEN: Brussels, Belgium, 2002.

11. International Organization for Standardization (ISO). ISO 2394 General Principles on Reliability for Structures; ISO: Geneva, Switzerland, 2015.

12. Klein Tank, A.M.G.; Zwiers, F.W. Guidelines on Analysis of Extremes in a Changing Climate in Support of Informed Decisions for Adaptation; World Meteorological Organization: Geneva, Switzerland, 2009.

13. Croce, P.; Formichi, P.; Landi, F. Evaluation of current trends of climatic actions in Europe based on observations and regional reanalysis. Remote Sens. 2021, 13, 2025. [CrossRef]

14. Matiu, M.; Petitta, M.; Notarnicola, C.; Zebisch, M. Evaluating snow in EURO-CORDEX regional climate models with observations for the European Alps: Biases and their relationship to orography, temperature, and precipitation mismatches. Atmosphere 2020, 11, 46. [CrossRef]

15. Hanzer, F.; Förster, K.; Nemec, J.; Strasser, U. Projected cryospheric and hydrological impacts of 21st century climate change in the Ötztal Alps (Austria) simulated using a physically based approach. Hydrol. Earth Syst. Sci. 2018, 22, 1593-1614. [CrossRef]

16. Biegus, A.; Rykaluk, K. Collapse of Katowice Fair Building. Eng. Fail. Anal. 2009, 16, 1643-1654. [CrossRef]

17. Strasser, U. Snow loads in a changing climate: New risks? Nat. Hazards Earth Syst. Sci. 2008, 8, 1-8. [CrossRef]

18. Ice Rink Roof Collapses Due to Snow. Available online: https://www.ansa.it/english/news/general_news/2021/02/10/icerink-roof-collapses-due-to-snow_9996af04-f0a0-43bc-8741-91269e2c7c3d.html (accessed on 25 June 2021).

19. Le Roux, E.; Evin, G.; Eckert, N.; Blanchet, J.; Morin, S. Non-stationary extreme value analysis of ground snow loads in the French Alps: A comparison with building standards. Nat. Hazards Earth Syst. Sci. 2020, 20, 2961-2977. [CrossRef]

20. Holicky, M.; Sykora, M. Failures of roofs under snow load: Causes and reliability analysis. J. Forensic Eng. 2009, 444-453. [CrossRef]

21. Croce, P.; Formichi, P.; Landi, F. Probabilistic methodology to assess impact of climate change on structural safety. In Proceedings of the 30th European Safety and Reliability Conference and the 15th Probabilistic Safety Assessment and Management Conference; Baraldi, P., Di Maio, F., Zio, E., Eds.; Research Publishing: Singapore, 2020; pp. 4758-4764. [CrossRef]

22. Anandhi, A.; Frei, A.; Pierson, D.C.; Schneiderman, E.M.; Zion, M.S.; Lounsbury, D.; Matonse, A.H. Examination of change factor methodologies for climate change impact assessment. Water Resour. Res. 2011, 47, W03501. [CrossRef]

23. Maraun, D. Bias Correcting climate change simulations-A critical review. Curr. Clim. Chang. Rep. 2016, 2, 211-220. [CrossRef]

24. Fatichi, S.; Ivanov, V.Y.; Caporali, E. Simulation of future climate scenarios with a weather generator. Adv. Water Resour. 2011, 34, 448-467. [CrossRef]

25. Ho, C.K.; Stephenson, D.B.; Collins, M.; Ferro, C.A.T.; Brown, S.J. Calibration strategies a source of additional uncertainty in climate change projections. Bull. Am. Meteorol. Soc. 2012, 93, 21-26. [CrossRef]

26. Jacob, D.; Petersen, J.; Eggert, B.; Alias, A.; Christensen, O.B.; Bouwer, L.M.; Braun, A.; Colette, A.; Déqué, M.; Georgievski, G.; et al. EURO-CORDEX: New high-resolution climate change projections for European impact research. Reg. Environ. Chang. 2014, 14, 563-578. [CrossRef]

27. Kotlarski, S.; Keuler, K.; Christensen, O.B.; Colette, A.; Déqué, M.; Gobiet, A.; Goergen, K.; Jacob, D.; Lüthi, D.; van Meijgaard, E.; et al. Regional climate modelling on european scale: A joint standard evaluation of the EURO-CORDEX ensemble. Geosci. Model Dev. 2014, 7, 1297-1333. [CrossRef] 
28. Van Vuuren, D.P.; Edmonds, J.; Kainuma, M.; Riahi, K.; Thomson, A.; Hibbard, K.; Hurtt, G.C.; Kram, T.; Krey, V.; Lamarque, J.F.; et al. The representative concentration pathways: An overview. Clim. Chang. 2011, 109, 5-31. [CrossRef]

29. M/515 EN-Mandate for Amending Existing Eurocodes and Extending the Scope of Structural Eurocodes; European Commission: Brussels, Belgium, 2012.

30. CEN/TC250-Response to Mandate M/515 ‘Towards a Second Generation of Eurocodes'; CEN-TC250-N 993; European Committee for Standardization (CEN): Brussels, Belgium, 2013.

31. Croce, P.; Formichi, P.; Landi, F.; Marsili, F. Harmonized European ground snow load map: Analysis and comparison of national provisions. Cold Reg. Sci. Technol. 2019, 168, 102875. [CrossRef]

32. Winkler, M.; Schellander, H.; Gruber, S. Snow water equivalents exclusively from snow depths and their temporal changes: The $\triangle$ SNOW model. Hydrol. Earth Syst. Sci. 2021, 25, 1165-1187. [CrossRef]

33. Sanpaolesi, L.; Del Corso, R.; Formichi, P.; Currie, D.; Sims, P.; Sacré, C.; Stiefel, U.; Lozza, S.; Eiselt, B.; Peckham, R.; et al. Phase 1 Final Report to the European Commission, Scientific Support Activity in the Field of Structural Stability of Civil Engineering Works: Snow Loads; Department of Structural Engineering, University of Pisa: Pisa, Italy, 1998. Available online: http:/ / www2.ing.unipi.it/ dic/snowloads/Final\%20Report\%20I.pdf (accessed on 7 April 2021).

34. European Committee for Standardization (CEN). EN 1991-1-3. Eurocode 1: Actions on Structures-Part 1-3: General Actions-Snow Loads; CEN: Brussels, Belgium, 2003.

35. Croce, P.; Formichi, P.; Landi, F. Probabilistic assessment of roof snow load and the calibration of shape coefficients in the eurocodes. Appl. Sci. 2021, 11, 2984. [CrossRef]

36. Del Corso, R.; Formichi, P. Statistics of ground snow loads in Italy. In Snow Engineering: Recent Advances and Developments, Proceedings of the 4th International Conference on Snow Engineering, Trondheim, Norway, 19-21 June 2000; TRB: Trondheim, Norway, 2000; pp. 161-166.

37. Thom, H.C.S. Distribution of maximum annual water equivalent of snow on the ground. Mon. Weather Rev. 1966, 94, 265-271. [CrossRef]

38. O'Gorman, P.A. Contrasting responses of mean and extreme snowfall to climate change. Nature 2014, 515, 416-418. [CrossRef]

39. Räisänen, J. Warmer climate: Less or more snow? Clim. Dyn. 2008, 30, 307-319. [CrossRef]

40. Scherrer, S.C.; Fischer, E.M.; Posselt, R.; Liniger, M.A.; Croci-Maspoli, M.; Knutti, R. Emerging trends in heavy precipitation and hot temperature extremes in Switzerland. J. Geophys. Res. Atmos. 2016, 121, 2626-2637. [CrossRef]

41. Ménégoz, M.; Valla, E.; Jourdain, N.C.; Blanchet, J.; Beaumet, J.; Wilhelm, B.; Gallée, H.; Fettweis, X.; Morin, S.; Anquetin, S. Contrasting seasonal changes in total and intense precipitation in the European Alps from 1903 to 2010. Hydrol. Earth Syst. Sci. 2020, 24, 5355-5377. [CrossRef]

42. Gobiet, A.; Kotlarski, S.; Beniston, M.; Heinrich, G.; Rajczak, J.; Stoffel, M. 21st century climate change in the European Alps-A review. Sci. Total Environ. 2014, 493, 1138-1151. [CrossRef]

43. Taylor, K.E.; Stouffer, R.J.; Meehl, G.A. An overview of CMIP5 and the experiment design. Bull. Am. Meteorol. Soc. 2012, 93, 485-498. [CrossRef]

44. Makkonen, L.; Ruokolainen, L.; Raisanen, J.; Tikanmaki, M. Regional Climate Model Estimates for Changes in Nordic Extreme Events. Geophysica 2007, 43, 25-48.

45. Räisänen, J.; Eklund, J. 21st Century changes in snow climate in Northern Europe: A high-resolution view from ENSEMBLES regional climate models. Clim. Dyn. 2012, 38, 2575-2591. [CrossRef]

46. Intergovernmental Panel on Climate Change (IPCC). Emission Scenarios. A Special Report of Working Group III of the Intergovernmental Panel on Climate Change; Technical Report; Cambridge University Press: Cambridge, UK, 2000.

47. Deutscher Wetterdienst (DWD). The Weather in Germany in the Winter 2018/19. Available online: https://www.dwd.de/EN/ press/press_release/EN/2019/20190227_the_weather_in_germany_in_winter_2018_2019.pdf?_blob=publicationFile\&v=2 (accessed on 25 June 2021).

48. Screen, J.; Furtado, J.; Cohen, J.; Barlow, M.; Whittleston, D.; Coumou, D.; Francis, J.; Dethloff, K.; Entekhabi, D.; Overland, J.; et al. Recent Arctic amplification and extreme mid-latitude weather. Nat. Geosci. 2014, 7, 627-637. [CrossRef]

49. Blackport, R.; Screen, J.A. Weakened evidence for mid-latitude impacts of Arctic warming. Nat. Clim. Chang. 2020, 10, 1065-1066. [CrossRef]

50. Hausfather, Z.; Peters, G. Emissions-The 'business as usual' story is misleading. Nature 2020, 577, 618-620. [CrossRef]

51. Schwalm, C.R.; Glendon, S.; Duffy, P.B. RCP8.5 tracks cumulative $\mathrm{CO}_{2}$ emissions. Proc. Natl. Acad. Sci. USA 2020, 117, 19656-19657. [CrossRef]

52. Burgess, M.G.; Ritchie, J.; Shapland, J.; Pielke, R., Jr. IPCC baseline scenarios have over-projected $\mathrm{CO}_{2}$ emissions and economic growth. Environ. Res. Lett. 2021, 16, 014016. [CrossRef]

53. Tebaldi, C.; Knutti, R. The use of the multi-model ensemble in probabilistic climate projections. Philos. Trans. R. Soc. A 2007, 365, 2053-2075. [CrossRef] [PubMed]

54. Croce, P.; Formichi, P.; Landi, F.; Marsili, F. Evaluating the effect of climate change on thermal actions on structures. In LifeCycle Analysis and Assessment in Civil Engineering: Towards an Integrated Vision; Caspeele, L., Taerwe, D., Frangopol, M., Eds.; Taylor \& Francis Group: Oxfordshire, UK, 2019; pp. 1751-1758. ISBN 978-1-138-62633-1.

55. Croce, P.; Formichi, P.; Landi, F. Enhancing the output of climate models: A weather generator for climate change impact studies. Atmosphere 2021, 12, 1074. [CrossRef] 
56. Evin, G.; Hingray, B.; Blanchet, J.; Eckert, N.; Morin, S.; Verfaillie, D. Partitioning uncertainty components of an incomplete ensemble of climate projections using data augmentation. J. Clim. 2019, 32, 2423-2440. [CrossRef]

57. Evin, G.; Somot, S.; Hingray, B. Balanced estimate and uncertainty assessment of European climate change using the large EURO-CORDEX regional climate model ensemble. Earth Syst. Dyn. Discuss. 2021. [CrossRef]

58. Croce, P.; Formichi, P.; Landi, F. Structural safety and design under climate change. In 20th IABSE Congress New York 2019: The Evolving Metropolis; IABSE: Zurich, Switzerland, 2019; pp. 1130-1135. ISBN 978-385748165-9.

59. Croce, P.; Formichi, P.; Landi, F. Implication of climate change on climatic actions on structures: The update of climatic load maps. In IABSE Symposium Wrocław 2020, Synergy of Culture and Civil Engineering-History and Challenges-Report; IABSE: Zurich, Switzerland, 2020; pp. 877-884.

60. Coles, S. An Introduction to Statistical Modelling of Extreme Values; Springer: London, UK, 2001.

61. Belote, R.T.; Carroll, C.; Martinuzzi, S.; Michalak, J.; Williams, J.W.; Williamson, M.A.; Aplet, G.H. Assessing agreement among alternative climate change projections to inform conservation recommendations in the contiguous United States. Sci. Rep. 2018, 8, 9441. [CrossRef]

62. Fontrodona Bach, A.; van der Schrier, G.; Melsen, L.A.; Klein Tank, A.M.G.; Teuling, A.J. Widespread and accelerated decrease of observed mean and extreme snow depth over Europe. Geophys. Res. Lett. 2018, 45, 312-319. [CrossRef]

63. Katz, R.W.; Brown, B.G. Extreme events in a changing climate: Variability is more important than averages. Clim. Chang. 1992, 21, 289-302. [CrossRef] 